\title{
Rancang Bangun Real-Time Business Intelligence Untuk Subjek Kegiatan Akademik pada Universitas Menggunakan Change Data Capture
}

\author{
Stephanie Pamela Adithama \\ Program Studi Teknik Informatika, Universitas Atma Jaya Yogyakarta \\ Jl. Babarsari 43, Yogyakarta 55281, Indonesia \\ E-mail: stephanie_pamela@staff.uajy.ac.id
}

\begin{abstract}
The running of academic activities in university continuously adds more data to the existing operational system. The data are not ready for the university strategic decision making, preparing reports for accreditation purposes and academic units. Real-time business intelligence application using data warehouse can become a solution for data analysis. The process of creating a data warehouse includes designing data warehouse, retrieving academic data from multiple data sources, extracting, transforming, loading (ETL) process, creating cube; and generating report. ETL processes are conducted by using a Pull Change Data Capture approach so that data changes during a certain period can be transferred in real-time. The higher the frequency of data change requests brings us closer to real-time and requires less time than loading all the data.
\end{abstract}

Keywords: real-time, business intelligence, data warehouse, academic, change data capture

\begin{abstract}
Abstrak. Kegiatan akademik di universitas berjalan terus menerus dan semakin menambah banyak data pada sistem operasional yang sudah ada. Data tersebut masih belum dapat dimanfaatkan oleh pihak universitas dalam pengambilan keputusan strategis, pembuatan laporan untuk keperluan akreditasi dan unit-unit akademik. Aplikasi real-time business intelligence menggunakan data warehouse menjadi solusi untuk analisa data. Proses pembuatan data warehouse meliputi perancangan data warehouse; pengambilan data akademik dari sumber data; proses extraction, transformation, loading (ETL); pembuatan cube; dan pembuatan laporan. Proses ETL dilakukan menggunakan pendekatan Change Data Capture Pull agar perubahan data selama periode tertentu dapat dipindahkan secara real-time. Semakin tinggi frekuensi permintaan perubahan data akan semakin mendekati real-time dan semakin membutuhkan waktu yang singkat dibandingkan dengan me-load semua data.
\end{abstract}

Kata Kunci: real-time, business intelligence, data warehouse, akademik, change data capture

\section{Pendahuluan}

Di universitas pada umumnya telah tersedia sistem yang digunakan untuk mengelola transaksi akademik di setiap fakultas dan pada unit-unit akademik. Penelitian ini menggunakan studi kasus di Universitas Atma Jaya Yogyakarta (UAJY), UAJY telah memiliki sistem yang digunakan untuk memenuhi kebutuhan transaksional data mahasiswa, dosen, kelas, nilai, jadwal, mata kuliah, krs, transkrip, lulusan, yang berhubungan dengan bidang akademik. Proses pembuatan keputusan dengan melakukan analisa terhadap data yang dihasilkan dari sistemsistem transaksional ini, tentu saja kurang efisien karena membutuhkan waktu yang cukup lama, dan tidak cukup akurat.

Akreditasi untuk institusi pendidikan tinggi dilakukan oleh Badan Akreditasi Nasional Perguruan Tinggi (BAN-PT). Persyaratan untuk mendapatkan akreditasi dari BAN-PT, institusi perguruan tinggi diwajibkan untuk mengisi borang akreditasi dan untuk dapat mengisi borang tersebut, diperlukan berbagai macam data dan informasi. Kebutuhan akan data dan informasi, 
bisa dipenuhi apabila perguruan tinggi telah memanfaatkan sistem informasi dan menggunakan Business Intelligence (BI) (Wilarso,2008).

BI merupakan salah satu bentuk implementasi yang mampu menjawab kebutuhan untuk menganalisis masalah-masalah dalam pengambilan keputusan. Secara ringkas, BI diartikan sebagai pengetahuan yang didapatkan dari hasil analisis data yang diperoleh dari kegiatan suatu organisasi (Kusnawi, 2008). BI meliputi topik-topik seperti data warehousing, Online Analytical Processing (OLAP), Extract Transform Loading (ETL), data mining, dan multidimensionalitas (Turban et.al., 2004). Kesuksesan bisnis membutuhkan analisis data dilakukan secara real-time (Azvine et.al., 2006). Real-time BI akan menjelajahi data warehouse yang bervolume besar dan secara cepat mendatangkan data dalam operasi bisnis. Real-time BI mengoptimalkan proses pengambilan keputusan dengan mengurangi untuk menghilangkan latensi dan menyediakan data kontekstual yang kaya dan secara langsung dapat ditindaklanjuti (Sandu, 2008; Botan et.al., 2009).

Di UAJY perubahan data mahasiswa, dosen, kelas, nilai, jadwal, mata kuliah, krs, transkrip dilakukan setiap semester. Perubahan data lulusan dilakukan setiap bulan ketika yudisium dan empat bulan sekali ketika ada wisuda. Perubahan data calon mahasiswa baru dapat terjadi setiap waktu karena proses penerimaan mahasiswa baru dilakukan melalui beberapa jalur, yang sudah dimulai sejak bulan September sampai Juli. Proses penerimaan yang berkelanjutan ini dan penambahan data pendaftar yang tidak dapat diprediksi menyebabkan kebutuhan data-data akademik khususnya data calon mahasiswa baru perlu segera ditindaklanjuti untuk analisis dan pembuatan laporan. Proses ETL tradisional dijalankan secara periodik pada interval tertentu, contohnya bulanan atau mingguan. Pendekatan ini telah dilakukan oleh perusahaan bertahun-tahun, namun kondisi sekarang ini membutuhkan cara ETL baru yang lebih efisien dan real-time (Attachmate Corp, 2005; Attunity, 2006). Solusi (Change Data Capture) CDC didesain dan diintegrasikan dengan proses ETL untuk memaksimalkan efisiensi ETL, meminimalisasi penggunaan sumber daya dengan memindahkan perubahan data saja, dan meminimalisasi latensi dalam pengiriman perubahan data pada konsumen (Jörg \& Deßloch, 2008).

Penelitian ini melakukan perancangan data warehouse dan pengembangan sistem realtime BI berbasis web menggunakan pendekatan CDC Pull. Konsep real-time diwujudkan dengan mengintegrasikan CDC dengan tool ETL menggunakan model CDC Pull yang secara periodik meminta perubahan data, setiap waktu menerima sekumpulan record yang merepresentasikan semua perubahan yang ditangkap sejak siklus permintaan terakhir. Skenario ini mirip dengan ETL tradisional, perbedaannya skenario ini menangkap dan memindahkan hanya data yang berubah saja selama periode tertentu.

\section{Tinjauan Pustaka}

\subsection{Data Warehouse}

Menurut pelopor konsep dan istilah data warehouse, William Inmon, data warehouse adalah sebuah koleksi data yang berorientasi subjek, terintegrasi, non-volatile, dan time-variant dalam rangka mendukung keputusan-keputusan manajemen (Inmon, 2005).

Ponniah (2010) menyebutkan karakteristik dari data warehouse adalah sebagai berikut: (1) Berorientasi Subjek: Data warehouse didesain untuk menganalisa data berdasarkan subjeksubjek tertentu dalam organisasi, bukan pada proses atau fungsi aplikasi tertentu. (2) Terintegrasi: Sumber data yang ada dalam data warehouse tidak hanya berasal dari data operasional (internal source) tetapi juga berasal dari data di luar sistem (external source). (3) Time-variant: Sistem operasional mengandung data yang bernilai sekarang sedangkan data dalam data warehouse mengandung data tidak hanya data terkini tetapi juga data masa lampau. (4) Non-volatile: Pada data warehouse hanya ada dua kegiatan memanipulasi data yaitu loading data (mengambil data) dan akses data.

Komponen-komponen data warehouse menurut Ponniah (2010) digambarkan pada Gambar 1. Komponen sumber data berada di sebelah kiri. Komponen data staging menyediakan tempat dengan satu set fungsi untuk membersihkan, mengubah, menggabungkan, 
mengkonversi, mencegah duplikasi data, dan menyiapkan data sumber untuk penyimpanan dan penggunaan dalam data warehouse, disebut Extraction, Transformation, and Loading (ETL). Di tengah, terdapat komponen penyimpanan data yang mengelola data warehouse. Komponen information delivery berada di sebelah kanan, menyediakan informasi dari data warehouse bagi pengguna.

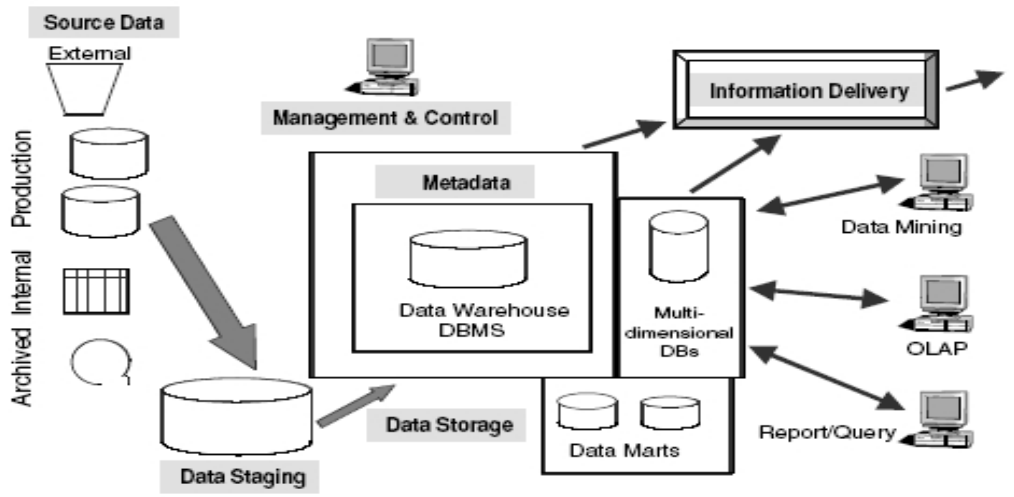

Gambar 1. Komponen Data Warehouse (Ponniah, 2010)

Pembuatan data warehouse didasarkan pada model data multidimensi. Model ini menampilkan data dalam bentuk kubus (cube), sebuah data dapat dipandang dari berbagai sudut. Komponen model multidimensional yang umum ditemukan dalam perancangan data warehouse (Prasetyo et.al., 2010): (1) Dimensi: kategori yang independen dari multidimensional basis data, mengandung item yang digunakan sebagai kriteria query. (2) Tabel Fakta: Mempunyai dua tipe kolom, yaitu kolom yang menyimpan nilai-nilai numerik (measure) dan kolom yang menyimpan foreign key yang mengacu ke tabel dimensi. (3) Measure: Cerminan dari fakta dan mengandung informasi kolom bertipe numerik yang akan dianalisa. (4) Hirarki: merupakan bentuk kesatuan dari dimensi. Sebuah dimensi bisa terbentuk dari multilevel, yang mempunyai parent-child relationship.

Model dimensional yang sering digunakan pada data warehouse (Prasetyo et.al., 2010): (1) Star schema, terdiri dari satu atau lebih tabel fakta dan satu atau lebih tabel dimensi. Tabel fakta merupakan pusat dari star schema, karena fungsinya sebagai pengikat dari tabel-tabel dimensi. (2) Snowflake schema, merupakan pengembangan dari star schema, tabel dimensi dinormalisasi secara sebagian atau keseluruhan untuk mengurangi nilai duplikat pada tabel.

\subsection{Change Data Capture (CDC)}

CDC adalah pendekatan inovasi untuk integrasi data, berdasarkan identifikasi, menangkap, dan mengirimkan perubahan yang dibuat oleh data sumber. Dengan memproses hanya perubahannya, $\mathrm{CDC}$ membuat proses integrasi data lebih efisien dan mengurangi biaya dengan mengurangi latensi (Attunity, 2006). CDC harus diintegrasikan dengan tool ETL sehingga proses ETL dapat efisien. Integrasi CDC dengan tool ETL yang ada menyediakan pendekatan terintegrasi untuk mengurangi jumlah informasi yang dikirimkan sambil meminimalisasi kebutuhan sumber daya dan memaksimalkan kecepatan dan efisiensi (Tank et.al., 2010).

Terdapat dua model skenario CDC pada Gambar 2 yang terintegrasi dengan tool ETL (Attachmate Corp, 2005): (1) Model CDC Pull: Tool ETL secara periodik meminta perubahan data, setiap waktu menerima sekumpulan record yang merepresentasikan semua perubahan yang ditangkap sejak siklus permintaan terakhir. Permintaan perubahan data dapat dalam frekuensi tinggi atau rendah. Skenario ini mirip dengan ETL tradisional, perbedaannya skenario ini menangkap dan memindahkan hanya data yang berubah saja. (2) Model CDC Push: Mekanisme pengiriman mengirim perubahan data ke tool ETL segera setelah perubahan terjadi. Metode ini membutuhkan tool ETL menggunakan listeners yang menunggu event perubahan 
dan publisher yang digunakan untuk mengirim dan memberikan notifikasi perubahan secara real-time.

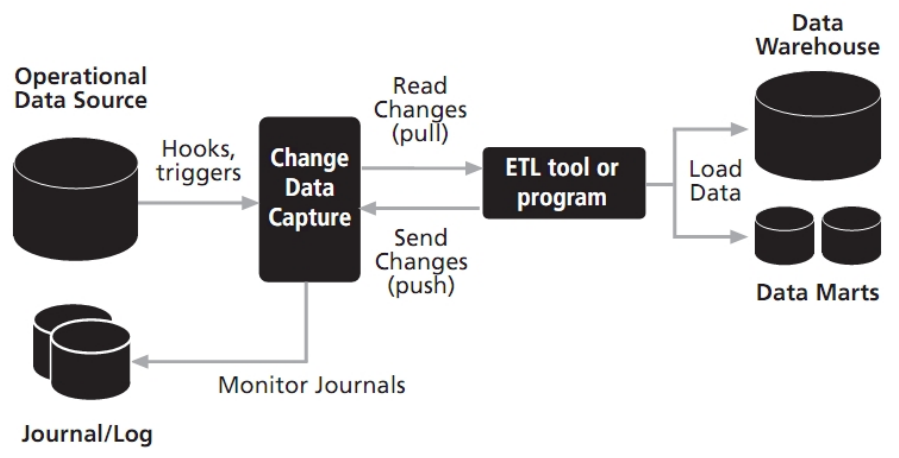

Gambar 2. Integrasi CDC Pada ETL (Attachmate Corp, 2005)

Pada SQL Server 2008, CDC menangkap dan merekam aktivitas insert, update, dan delete pada database OLTP dan menyimpannya dalam bentuk yang mudah digunakan oleh aplikasi, seperti SSIS package. Package ini digunakan untuk mengambil data dan menyimpannya pada server OLAP. Gambar 3 merepresentasikan gambaran komponen utama pada arsitektur CDC di SQL Server 2008. Diagram ini dibagi menjadi dua bagian, bagian atas merepresentasikan server OLTP dan bagian bawah merepresentasikan server OLAP.

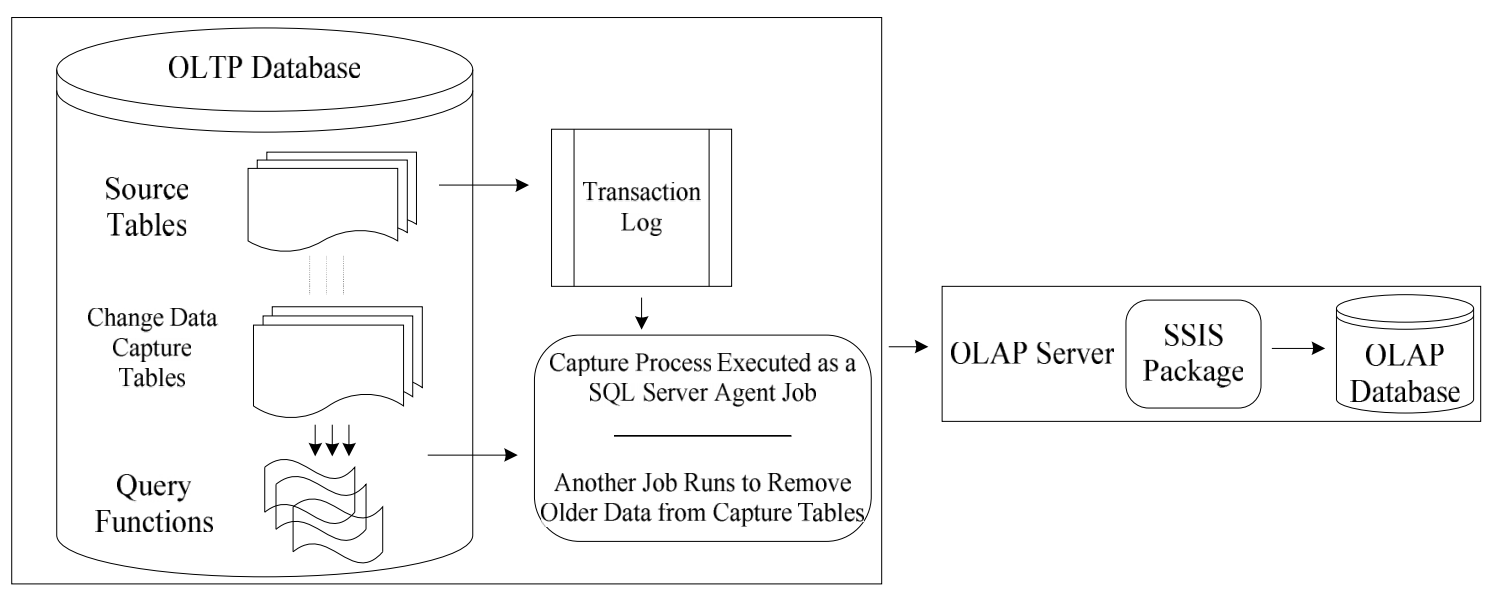

Gambar 3. Arsitektur CDC di SQL Server 2008 (McGehee, 2008)

Komponen-komponen CDC pada Gambar 3 dijelaskan sebagai berikut (McGehee, 2008): (1) Tabel sumber: ketika SQL Server pertama kali diinstall, secara default CDC dimatikan sehingga langkah pertama adalah mengaktifkan CDC pada level database, kemudian CDC harus diaktifkan pada level tabel. Setiap tabel yang CDC-nya aktif disebut dengan tabel sumber. (2) Tabel CDC: Setiap tabel sumber yang CDC-nya aktif, diciptakan tabel CDC yang berhubungan, yang digunakan untuk menyimpan perubahan yang dibuat di tabel sumber, bersama dengan beberapa metadata yang digunakan untuk menelusuri perubahan. (3) Fungsi Query CDC: setiap tabel sumber yang CDC-nya aktif, beberapa fungsi query CDC diciptakan untuk mengakses tabel CDC. (4) Capture dan Cleanup Jobs: dua SQL Server Agent jobs juga diciptakan, Capture job secara umum berjalan terus menerus dan digunakan untuk memindahkan perubahan data ke tabel CDC dari transaction log. Cleanup job dijalankan terjadwal untuk menghapus data lama pada tabel CDC sehingga tidak membengkak terlalu besar.

Cara kerja CDC sesuai dengan Gambar 3, adalah (McGehee, 2008): ketika ada kegiatan insert, update, atau delete yang terjadi pada tabel sumber, perubahan ini ditulis pada transaction log pada database. Hal ini normal, terjadi pula walaupun CDC tidak diaktifkan. Perbedaannya, 
ketika CDC diaktifkan pada tabel sumber, SQL Server Agent Capture job membaca perubahan pada transaction log dan memindahkannya ke tabel CDC yang tepat. Insert dan delete masingmasing menghasilkan satu baris pada tabel CDC, dan update menghasilkan dua baris: satu baris data sebelum dan satu baris data setelah perubahan. Perubahan ini terus diakumulasikan pada tabel CDC sampai dihapus oleh Cleanup Job. Perubahan data dari tabel CDC diekstrak dengan menjalankan statemen yang sesuai menggunakan fungsi query yang relevan, yang mengizinkan untuk mengekstrak semua perubahan yang dibuat pada tabel sumber sejak terakhir kali SSIS package dieksekusi, dan kemudian memindahkannya ke database pada server OLAP.

\section{Metodologi Penelitian}

Metodologi yang digunakan dalam pembangunan apikasi real-time BI untuk subjek kegiatan akademik pada universitas terdiri dari empat tahap utama yaitu: (1) Analisis. Pada tahap ini dilakukan analisis kebutuhan dan menganalisis data-data yang dibutuhkan untuk merancang data warehouse. Dilakukan dengan melakukan pengamatan pada Buku Pedoman Akreditasi Institusi Perguruan Tinggi, Buku Pedoman Akreditasi Program Studi Sarjana, dan permintaan-permintaan kebutuhan data akademik dari fakultas-fakultas, rektorat, dan unit-unit. (2) Perancangan. Pada tahap ini dilakukan perancangan data warehouse yaitu: merancang star skema, merancang tabel dimensi dan tabel fakta, menentukan pemetaan tabel dan kolom pada data sumber yang akan diambil. (3) Pengkodean. Pembangunan sistem dilakukan melalui beberapa tahap, yaitu: proses ETL dengan CDC dan loading data sumber ke staging area, membangun tabel dimensi dan tabel fakta pada data warehouse, loading data dari staging area ke data warehouse, membangun cube, menambahkan measure, mendefinisikan kalkulasi, membuat laporan BI berbasis web. (4) Pengujian. Pada tahap ini dilakukan proses pengujian fungsionalitas sistem yang telah dibangun.

\section{Pembahasan dan Pengujian \\ 4.1. Pembahasan}

Analisis terhadap sumber data dilakukan untuk mengetahui informasi yang harus disediakan oleh sistem, fungsi-fungsi yang dapat ditangani seperti: (1) Melihat profil jumlah dan kinerja calon mahasiswa dilihat dari berbagai dimensi. (2) Melihat profil jumlah dan kinerja lulusan dilihat dari berbagai dimensi. (3) Melihat profil, jumlah, dan kinerja semua mahasiswa dilihat dari berbagai dimensi. (4) Melihat profil perkuliahan dari berbagai dimensi. (5) Melihat profil transaksi status studi semua mahasiswa dilihat dari berbagai dimensi. Dari fungsi-fungsi tersebut dibuat sebuah skema model data. Gambar 4 merupakan star dan snowflake skema yang digunakan untuk membangun data warehouse.

Pendekatan yang digunakan dalam penelitian ini menggunakan model CDC Pull yang mirip dengan ETL tradisional, namun proses hanya dilakukan untuk data sumber yang berubah saja, bukan keseluruhan data sumber. SSIS package akan meminta perubahan secara periodik yaitu akan dieksekusi per menit, setiap hari. Sekumpulan record yang diterima merepresentasikan perubahan yang ditangkap sejak permintaan perubahan terakhir. CDC dipasang untuk menangkap perubahan yang terjadi pada database sumber dan pada tabel-tabel di database sumber yang terkait. Dalam proses pembuatan data warehouse, komponenkomponen diaplikasikan menjadi tahapan seperti model pada Gambar 5.

Ketika SQL Server 2008 pertama kali diinstall, CDC dimatikan secara default sehingga langkah pertama yang harus dilakukan adalah mengaktifkan CDC pada level database dan pada level tabel. Database-database sumber yaitu database perkuliahan, kemahasiswaan, dan calon mahasiswa baru diaktifkan CDC-nya. Ketika sudah berhasil diaktifkan, pada system tables akan ditemukan beberapa tabel cdc yang otomatis ditambahkan, yang berisi semua perubahan pada tabel sumber. Pada tabel CDC tersebut terdapat kolom-kolom yang sama persis dengan tabel sumbernya, ditambah dengan lima kolom baru yaitu: _\$start_lsn , _\$end_lsn , _\$seqval ,

Soperation, _Supdate_mask. Kolom _ \$operation merupakan kolom yang penting karena mengandung nilai yang berhubungan dengan operasi DML, yaitu: Delete $=1$, Insert $=2$, nilai sebelum Update $=3$, nilai sesudah Update $=4$. 


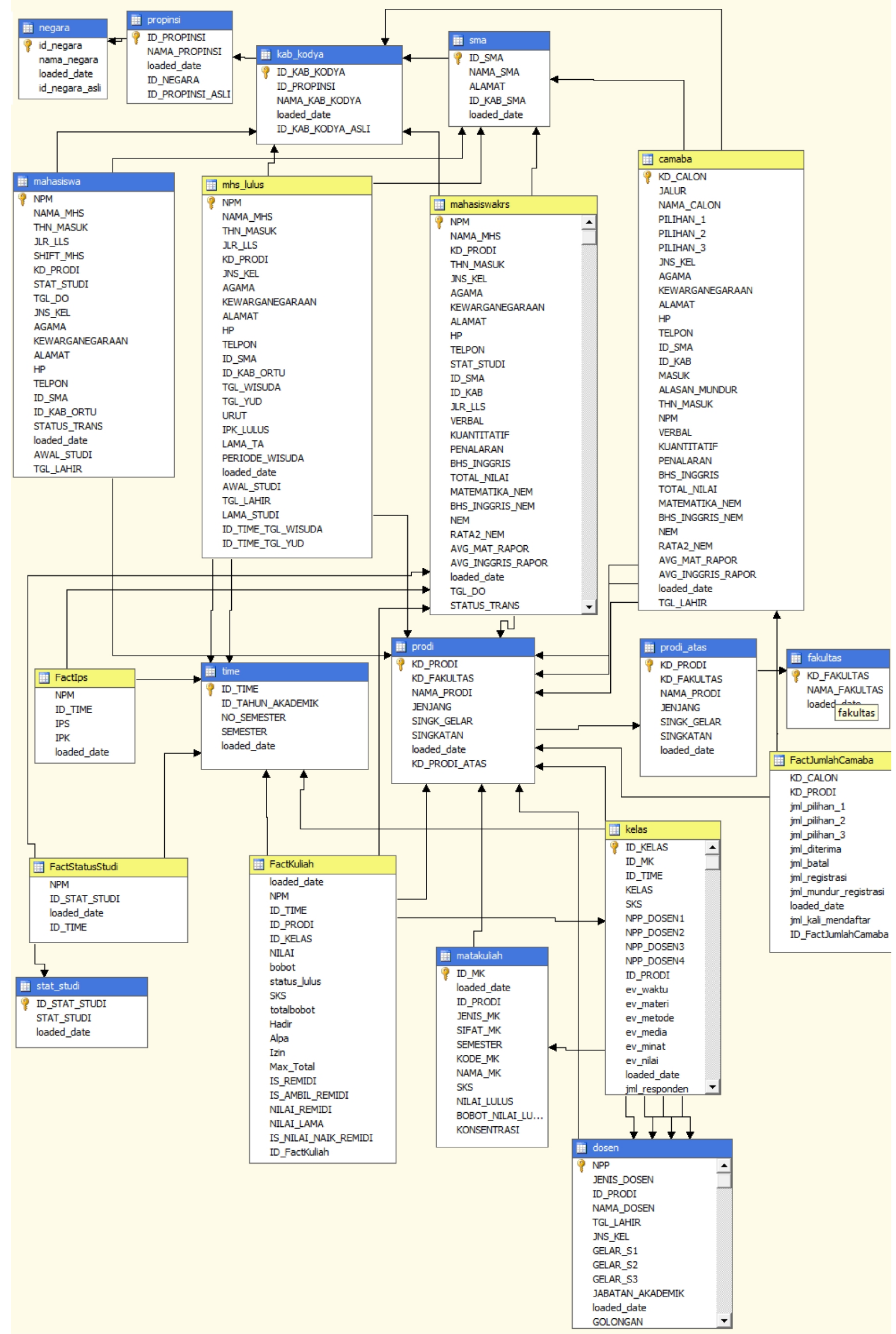

Gambar 4. Star dan Snowflake Skema BI Akademik 


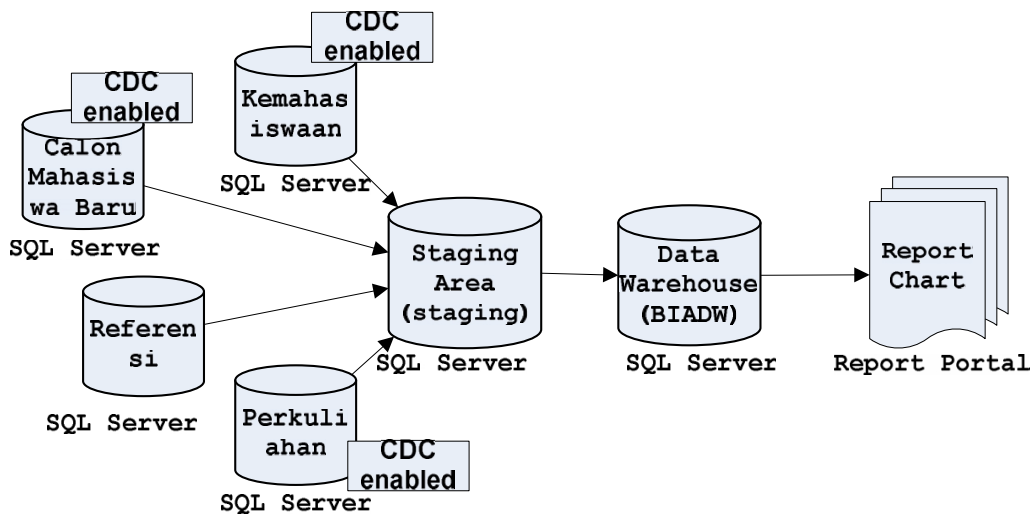

Gambar 5. Rancangan Tahap-Tahap Pembangunan

Control flow pada Gambar 6 merupakan cuplikan flow untuk menangani calon mahasiswa baru, yang akan memindahkan perubahan pada tabel MHS_PENDAFTAR dari database sumber menuju ke tabel camaba di database staging dan tabel camaba di data warehouse.

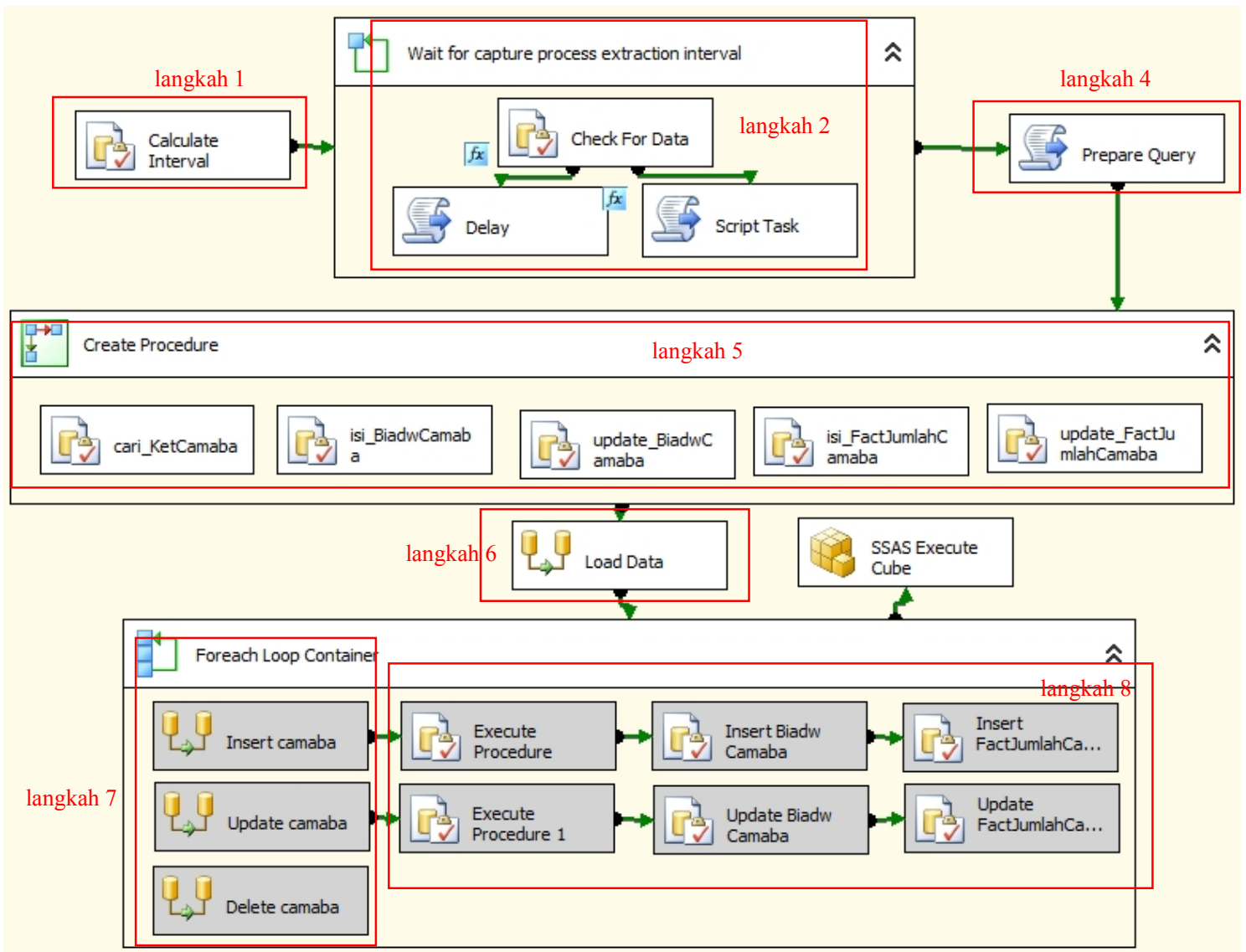

Gambar 6. Control Flow pada SSIS Package

Langkah-langkah untuk membuat control flow pada SSIS package yang terintegrasi dengan CDC secara umum adalah sebagai berikut: (1) Menentukan interval perubahan data, menghitung interval waktu mulai dan waktu selesai untuk perubahan pada sumber data yang ingin diambil. Studi kasus ini menggunakan interval tetap dan berasumsi bahwa package dijalankan setiap hari tanpa pengecualian. Waktu mulai untuk interval ini adalah waktu sekarang dikurangi satu menit. Waktu selesai untuk interval ini adalah waktu sekarang, yang 
nanti akan dipicu oleh SQL Server Agents Jobs yang akan menjalankan package setiap menit. (2) Menentukan kesiapan data pada interval yang telah dipilih sebelumnya, diperlukan karena data yang tidak sinkron akan menyebabkan kegagalan pada pemrosesan perubahan data. (3) Membuat table-valued function untuk mengambil perubahan data, hanya perlu diciptakan satu kali, dan berfungsi untuk mengakses tabel CDC, untuk mengambil perubahan data. (4) Mempersiapkan query untuk mengambil perubahan data, menggunakan Script Task untuk membangun statemen SQL yang akan digunakan untuk melakukan query untuk mengambil perubahan. Statemen SQL ini akan menggunakan fungsi table-valued function yang telah dibuat pada langkah sebelumnya. (5) Membuat prosedur, menambahkan Sequence Container dan menambahkan Execute SQL Task ke dalamnya. Prosedur-prosedur ini merupakan prosedur untuk transformasi dan pembersihan data. (6) Mengambil perubahan data, menambahkan Data Flow task seperti pada Gambar 7, yang akan mengambil record-record perubahan data, melakukan beberapa perubahan, dan akan menyimpannya dalam recordset, sebelum dapat digunakan pada langkah selanjutnya. (7) Memisahkan operasi insert, update, delete, dan memprosesnya pada tabel tujuan. Menambahkan Data Flow task seperti pada Gambar 8 untuk masing-masing operasi. Data Flow task ini akan mengambil nilai-nilai pada variable package, melakukan beberapa perubahan, dan akan melakukan operasi insert, update, atau delete pada database tujuan. Script Component ini akan mengambil nilai-nilai yang disimpan pada variable package dan akan mengeluarkannya melalui Output Columns. (8) Mengeksekusi prosedur, menambahkan Execute SQL Task untuk mengeksekusi prosedur yang diperlukan untuk melengkapi proses insert dan update. Execute SQL Task juga mengeksekusi prosedur yang melakukan proses insert dan update ke data warehouse. (9) Mengatur data flow task yang aktif (enable) sesuai dengan operasi yang terjadi pada record. Pada operasi insert, data flow task insert akan aktif (enable) jika operasi CDC adalah 'I', yang artinya record merupakan operasi insert dan belum ada pada tabel tujuan. Pada operasi update, data flow task update akan aktif (enable) jika operasi CDC adalah ' $\mathrm{U}$ ', yang artinya record merupakan operasi update. Pada operasi delete, data flow task delete akan aktif (enable) jika operasi CDC adalah 'D', yang artinya record merupakan operasi delete.

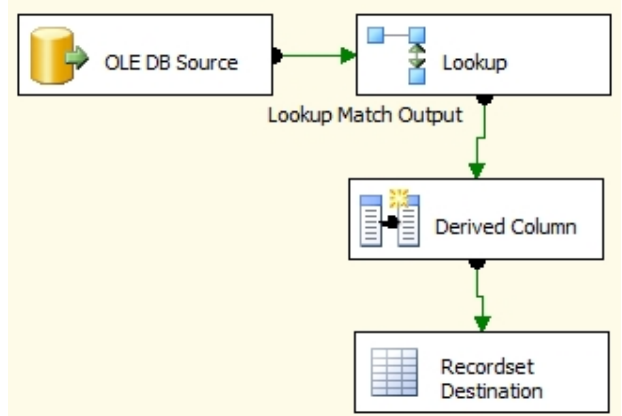

Gambar 7. Desain Data Flow Pada Langkah 6

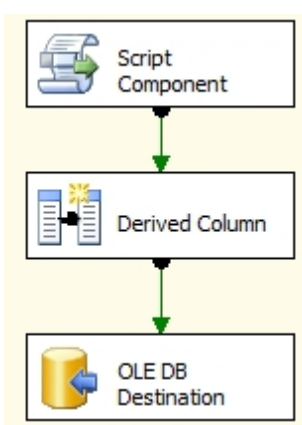

Gambar 8. Desain Data Flow Pada Langkah 7

\subsection{Pengujian}

Konsep real-time pada penelitian ini merupakan model Pull, dimana tool ETL secara periodik meminta perubahan data. Permintaan perubahan data dapat dalam frekuensi tinggi atau rendah, semakin tinggi frekuensi permintaan perubahan data maka akan semakin mendekati real-time. Skenario ini menangkap dan memindahkan hanya data yang berubah saja. SSIS package akan meminta perubahan secara periodik yaitu akan dieksekusi per menit dan dilakukan oleh SQL Server Agent Jobs. Skenario pengujian: (1) Mengatur SQL Server Agent $J o b$ agar mengeksekusi package setiap menit setiap hari. (2) Meng-insert-kan 11 data pada menit ke-0, dengan asumsi perubahan pada tabel MHS_PENDAFTAR dengan selang waktu hanya satu menit tidak akan terlalu banyak. Data yang di-insert-kan seperti pada Gambar 9, mempunyai isi yang sama persis dengan KD_CALON '10110340' dan '12113008', tetapi mempunyai KD_CALON yang berbeda-beda, agar lebih mudah dalam mencocokkan 
kesesuaian data. Selain itu di-insert-kan juga data pendukung ke tabel-tabel yang berhubungan. Operasi insert tersebut akan dipindahkan secara otomatis dari transaction log ke tabel CDC yang secara otomatis terbentuk saat CDC diaktifkan, yaitu tabel cdc.dbo_mhs_pendaftar_CT seperti pada Gambar 10. Pada kolom _ \$operation nilai 2 menandakan operasi insert, dan kolom-kolom setelahnya menyimpan data-data dari baris yang di-insert-kan.

\begin{tabular}{|c|c|c|c|c|c|c|c|c|c|c|c|}
\hline \multicolumn{12}{|c|}{ 畨 Results 呞 Messages } \\
\hline & KD_CALON & KD_JALUR & ID_ORTU & NM_CALON & PILIHAN_1 & PILIHAN_2 & PILIHAN_3 & JNS_KEL & TMP_LAHIR & TGL_LAHIR & ALAMAT_SURA \\
\hline 1 & 12113008 & 11 & NULL & RUTH KARLINA & 09 & 10 & 00 & NULL & NULL & NULL & JALAN PEMUD $f$ \\
\hline 2 & 10110340 & 5 & 2762 & DWI KURNIAWAN & 09 & 00 & 00 & $\mathrm{~L}$ & JEMBER & $1989-01-1400: 00: 00.000$ & NAYAN MAGUV \\
\hline 3 & 00110000 & 5 & 2762 & DWI KURNIAWAN & 09 & 00 & 00 & $L$ & JEMBER & $1989-01-1400: 00: 00.000$ & NAYAN MAGUV \\
\hline 4 & 10110000 & 5 & 2762 & DWI KURNIAWAN & 09 & 00 & 00 & L & JEMBER & 1989-01-14 00:00:00.000 & NAYAN MAGUV \\
\hline 5 & 20110000 & 5 & 2762 & DWI KURNIAWAN & 09 & 00 & 00 & L & JEMBER & $1989-01-1400: 00: 00.000$ & NAYAN MAGUV \\
\hline 6 & 30110000 & 5 & 2762 & DWI KURNIAWAN & 09 & 00 & 00 & L & JEMBER & 1989-01-14 00:00:00.000 & NAYAN MAGUV \\
\hline 7 & 40110000 & 5 & 2762 & DWI KURNIAWAN & 09 & 00 & 00 & L & JEMBER & $1989-01-1400: 00: 00.000$ & NAYAN MAGUV \\
\hline 8 & 50110000 & 5 & 2762 & DWI KURNIAWAN & 09 & 00 & 00 & L & JEMBER & $1989-01-1400: 00: 00.000$ & NAYAN MAGUV \\
\hline 9 & 60110000 & 5 & 2762 & DWI KURNIAWAN & 09 & 00 & 00 & L & JEMBER & $1989-01-1400: 00: 00.000$ & NAYAN MAGUV \\
\hline 10 & 70110000 & 5 & 2762 & DWI KURNIAWAN & 09 & 00 & 00 & L & JEMBER & $1989-01-1400: 00: 00.000$ & NAYAN MAGUV \\
\hline 11 & 80110000 & 5 & 2762 & DWI KURNIAWAN & 09 & 00 & 00 & L & JEMBER & $1989-01-1400: 00: 00.000$ & NAYAN MAGUV \\
\hline 12 & 90110000 & 5 & 2762 & DWI KURNIAWAN & 09 & 00 & 00 & L & JEMBER & $1989-01-1400: 00: 00.000$ & NAYAN MAGUV \\
\hline 13 & 12110000 & 11 & NULL & RUTH KARLINA & 09 & 10 & 00 & NULL & NULL & NULL & JALAN PEMUDA \\
\hline
\end{tabular}

Gambar 9. Data Baru di Database Sumber Tabel MHS_PENDAFTAR

SELECT * FROM Mission.cdc.dbo_mhs_pendaftar_CT

\begin{tabular}{|c|c|c|c|c|c|c|c|c|c|c|}
\hline \multicolumn{11}{|c|}{ Results 道 Messages } \\
\hline \multicolumn{2}{|r|}{ _Sstart_lsn } & \multirow{2}{*}{ NULL_ } & \multirow{2}{*}{$\begin{array}{l}\text {-Sseqval } \\
\text { Ox000002D2000001810007 }\end{array}$} & \multirow{2}{*}{${ }_{2}^{\text {Soperation }}$} & _Supdate_mask & KD_CALON & KD_JALUR & \multirow{2}{*}{2762} & NM_CALON & PILIHAN_1 \\
\hline \multicolumn{2}{|r|}{$0 \times 000002 D 2000001810008$} & & & & Qx3FFFFFFFFF & 00110000 & 5 & & DWI KURNIAWAN & 09 \\
\hline & Qx000002D20000018A0008 & NULL & Qx000002D20000018A0007 & 2 & Q $\times 3$ FFFFFFFFF & 10110000 & 5 & \multirow{2}{*}{$\begin{array}{l}2762 \\
2762\end{array}$} & DWI KURNIAWAN & 09 \\
\hline & Ox000002D2000001930008 & NULL & Qx000002D2000001930007 & 2 & Qx3FFFFFFFFF & 20110000 & 5 & & DWI KURNIAWAN & \multirow{2}{*}{$\begin{array}{l}09 \\
09\end{array}$} \\
\hline & $0 \times 000002020000019 C 0009$ & NULL & Qx000002D20000019C0008 & 2 & Qx3FFFFFFFFF & 30110000 & 5 & 2762 & DWI KURNIAWAN & \\
\hline & \multirow{2}{*}{$\begin{array}{l}\text { Ox000002D2000001A50009 } \\
\text { Ox000002D2000001AE0008 }\end{array}$} & NULL & $0 \times 000002 \mathrm{D} 2000001 \mathrm{~A} 50007$ & 2 & Qx3FFFFFFFFF & 40110000 & 5 & 2762 & DWI KURNIAWAN & 09 \\
\hline & & NULL & Ox000002D2000001AE0007 & 2 & Qx3FFFFFFFFF & 50110000 & 5 & 2762 & DWI KURNIAWAN & 09 \\
\hline & Ox000002D2000001B70008 & NULL & Qx000002D2000001870007 & 2 & Qx3FFFFFFFFF & 60110000 & 5 & 2762 & DWI KURNIAWAN & 09 \\
\hline & Qx000002D2000001C00008 & NULL & Qx000002D2000001C00007 & 2 & OX3FFFFFFFFF & 70110000 & 5 & 2762 & DWI KURNIAWAN & 09 \\
\hline & \multirow{2}{*}{$\begin{array}{l}\text { Ox000002D 2000001C90008 } \\
0 \times 000002 D 2000001020008\end{array}$} & NULL & $0 \times 000002 D 2000001 C 90007$ & 2 & Q $\times 3 F F F F F F F F F$ & 80110000 & 5 & 2762 & DWI KURNIAWAN & 09 \\
\hline & & NULL & Qx000002D2000001D20007 & 2 & Q $\times 3$ FFFFFFFFF & 90110000 & 5 & \multirow{2}{*}{$\begin{array}{l}2762 \\
\text { NULL }\end{array}$} & DWI KURNIAWAN & \multirow{2}{*}{$\begin{array}{l}09 \\
09\end{array}$} \\
\hline & Ox000002D2000001DB0009 & NULL & Cx000002D2000001DB0007 & 2 & Q $\times 3$ FFFFFFFFF & 12110000 & 11 & & RUTH KARLINA & \\
\hline
\end{tabular}

Gambar 10. Isi Tabel CDC cdc.dbo_mhs_pendaftar_CT

Selanjutnya, (3) SQL Server Agent Job pada menit ke-1 akan langsung mengeksekusi package CDC, dan memproses perubahan data yang dibuat sebelumnya. Baris-baris pada tabel CDC cdc.dbo_mhs_pendaftar_CT akan di-load ke database staging tabel camaba (Gambar 11), dan diteruskan ke database biadw tabel camaba (Gambar 12) dan FactJumlahCamaba (Gambar 13), sekaligus memproses cube-nya. (4) Pada Gambar 14, report pada saat itu juga akan langsung tertampil mahasiswa baru yang tadi ditambahkan.

\begin{tabular}{|c|c|c|c|c|c|c|c|c|c|c|c|c|}
\hline \\
\hline \multicolumn{13}{|c|}{ Tesults } \\
\hline & KD_CALON & JALUR & NAMA_CALON & PILIHAN_1 & PILIHAN_2 & PILIHAN_3 & JNS_KEL & AGAMA & ID_SMA & ID_KAB & MASUK & ALASAN_MUNDUR \\
\hline 1 & 00110000 & UNGGULAN NEM & DWI KURNIAWAN & 09 & NULL & NULL & L & Islam & 92475 & 392 & 09 & \\
\hline 2 & 10110000 & UNGGULAN NEM & DWI KURNIAWAN & 09 & NULL & NULL & L & Islam & 92475 & 392 & 09 & \\
\hline 3 & 20110000 & UNGGULAN NEM & DWI KURNIAWAN & 09 & NULL & NULL & L & Islam & 92475 & 392 & 09 & \\
\hline 4 & 30110000 & UNGGULAN NEM & DWI KURNIAWAN & 09 & NULL & NULL & L & Islam & 92475 & 392 & 09 & \\
\hline 5 & 40110000 & UNGGULAN NEM & DWI KURNIAWAN & 09 & NULL & NULL & $\mathrm{L}$ & Islam & 92475 & 392 & 09 & \\
\hline 6 & 50110000 & UNGGULAN NEM & DWI KURNIAWAN & 09 & NULL & NULL & L & Islam & 92475 & 392 & 09 & \\
\hline 7 & 60110000 & UNGGULAN NEM & DWI KURNIAWAN & 09 & NULL & NULL & L & Islam & 92475 & 392 & 09 & \\
\hline 8 & 70110000 & UNGGULAN NEM & DWI KURNIAWAN & 09 & NULL & NULL & L & Islam & 92475 & 392 & 09 & \\
\hline 9 & 80110000 & UNGGULAN NEM & DWI KURNIAWAN & 09 & NULL & NULL & L & Islam & 92475 & 392 & 09 & \\
\hline 10 & 90110000 & UNGGULAN NEM & DWI KURNIAWAN & 09 & NULL & NULL & $\mathrm{L}$ & Islam & 92475 & 392 & 09 & \\
\hline 11 & 12110000 & REGULER III & RUTH KARLINA & 09 & 10 & NULL & - & NA & 92448 & 1 & NULL & \\
\hline 12 & 12113008 & REGULER III & RUTH KARLINA & 09 & 10 & NULL & - & NA & 92448 & 1 & NULL & \\
\hline & 10110340 & UNGGULAN NEM & DWI KURNIAWAN & 09 & & NULL & & & 92475 & 392 & & \\
\hline
\end{tabular}

\section{Gambar 11. Data Baru di Database Staging Tabel Camaba}




\begin{tabular}{|c|c|c|c|c|c|c|c|c|c|c|c|c|}
\hline \multicolumn{13}{|l|}{1} \\
\hline \multicolumn{13}{|c|}{ Results 目 Messages } \\
\hline & KD_CALON & JALUR & NAMA_CALON & PILIHAN_1 & PILIHAN_2 & PILIHAN_3 & JNS_KEL & AGAMA & ID_SMA & ID_KAB & MASUK & ALASAN_M \\
\hline 1 & 00110000 & UNGGULAN NEM & DWI KURNIAWAN & 09 & NULL & NULL & $\mathrm{L}$ & Islam & 92475 & 392 & 09 & \\
\hline 2 & 10110000 & UNGGULAN NEM & DWI KURNIAWAN & 09 & NULL & NULL & $L$ & Islam & 92475 & 392 & 09 & \\
\hline 3 & 10110340 & UNGGULAN NEM & DWI KURNIAWAN & 09 & NULL & NULL & $\mathrm{L}$ & Islam & 92475 & 392 & 09 & \\
\hline 4 & 12110000 & REGULER III & RUTH KARLINA & 09 & 10 & NULL & $\cdot$ & NA & 92448 & 1 & NULL & \\
\hline 5 & 12113008 & REGULER III & RUTH KARLINA & 09 & 10 & NULL & - & NA & 92448 & 1 & NULL & \\
\hline 6 & 20110000 & UNGGULAN NEM & DWI KURNIAWAN & 09 & NULL & NULL & $\mathrm{L}$ & Islam & 92475 & 392 & 09 & \\
\hline 7 & 30110000 & UNGGULAN NEM & DWI KURNIAWAN & 09 & NULL & NULL & L & Islam & 92475 & 392 & 09 & \\
\hline 8 & 40110000 & UNGGULAN NEM & DWI KURNIAWAN & 09 & NULL & NULL & L & Islam & 92475 & 392 & 09 & \\
\hline 9 & 50110000 & UNGGULAN NEM & DWI KURNIAWAN & 09 & NULL & NULL & L & Islam & 92475 & 392 & 09 & \\
\hline 10 & 60110000 & UNGGULAN NEM & DWI KURNIAWAN & 09 & NULL & NULL & L & Islam & 92475 & 392 & 09 & \\
\hline 11 & 70110000 & UNGGULAN NEM & DWI KURNIAWAN & 09 & NULL & NULL & L & Islam & 92475 & 392 & 09 & \\
\hline 12 & 80110000 & UNGGULAN NEM & DWI KURNIAWAN & 09 & NULL & NULL & L & Islam & 92475 & 392 & 09 & \\
\hline 13 & 90110000 & UNGGULAN NEM & DWI KURNIAWAN & 09 & NULL & NULL & $\mathrm{L}$ & Islam & 92475 & 392 & 09 & \\
\hline
\end{tabular}

Gambar 12. Data Baru di Database biadw Tabel Camaba

\begin{tabular}{|c|c|c|c|c|c|c|c|c|}
\hline \multicolumn{9}{|c|}{ "'! } \\
\hline \multicolumn{9}{|c|}{ Results 局 Messages } \\
\hline & KD_CALON & KD_PRODI & jml_pilihan_1 & jml_pilihan_2 & jml_pilihan_3 & jml_diterima & jml_registrasi & loaded_date \\
\hline 1 & 10110340 & 09 & 1 & 0 & 0 & 1 & 1 & $2012-11-2604: 17: 18.523$ \\
\hline 2 & 12113008 & 09 & 1 & 0 & 0 & 0 & 0 & 2012-11-26 04:18:44.163 \\
\hline 3 & 12113008 & 10 & 0 & 1 & 0 & 0 & 0 & $2012-11-26$ 04:18:44.163 \\
\hline 4 & 00110000 & 09 & 1 & 0 & 0 & 1 & 0 & 2013-04-16 23:35:04.797 \\
\hline 5 & 10110000 & 09 & 1 & 0 & 0 & 1 & 0 & 2013-04-16 23:35:05.157 \\
\hline 6 & 20110000 & 09 & 1 & 0 & 0 & 1 & 0 & 2013-04-16 23:35:05.500 \\
\hline 7 & 30110000 & 09 & 1 & 0 & 0 & 1 & 0 & $2013-04-1623: 35: 05.843$ \\
\hline 8 & 40110000 & 09 & 1 & 0 & 0 & 1 & 0 & 2013-04-16 23:35:06.210 \\
\hline 9 & 50110000 & 09 & 1 & 0 & 0 & 1 & 0 & 2013-04-16 23:35:06.537 \\
\hline 10 & 60110000 & 09 & 1 & 0 & 0 & 1 & 0 & 2013-04-16 23:35:06.850 \\
\hline 11 & 70110000 & 09 & 1 & 0 & 0 & 1 & 0 & 2013-04-16 23:35:07.180 \\
\hline 12 & 80110000 & 09 & 1 & 0 & 0 & 1 & 0 & 2013-04-16 23:35:07.527 \\
\hline 13 & 90110000 & 09 & 1 & 0 & 0 & 1 & 0 & 2013-04-16 23:35:07.837 \\
\hline 14 & 12110000 & 09 & 1 & 0 & 0 & 0 & 0 & 2013-04-16 23:35:08.027 \\
\hline 15 & 12110000 & 10 & 0 & 1 & 0 & 0 & 0 & 2013-04-16 23:35:08.027 \\
\hline
\end{tabular}

Gambar 13. Data Baru di Database biadw Tabel FactJumlahCamaba

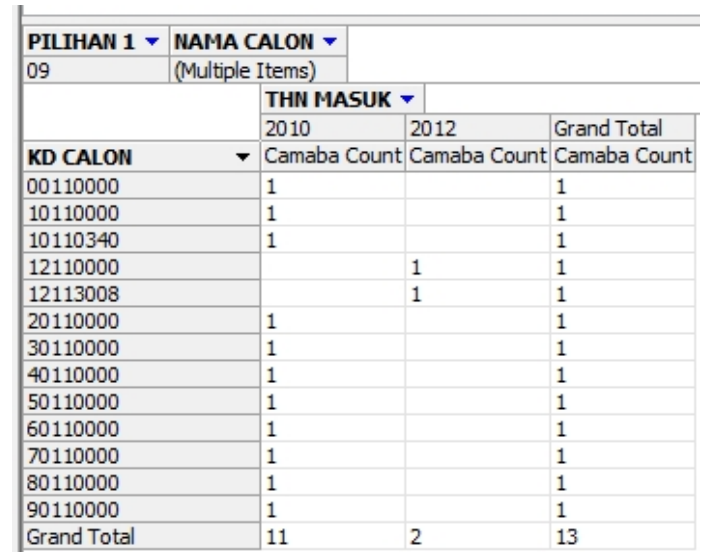

Gambar 14. Data Baru pada Report

Berdasarkan pengujian di atas, pada Tabel 1 dapat disimpulkan untuk mengeksekusi 11 perubahan data mulai dari proses insert ke tabel sumber hingga bisa ditampilkan di browser laporan memerlukan waktu satu menit, sehingga dengan semakin tingginya frekuensi periode permintaan perubahan data akan semakin mendekati real-time. 
Tabel 1. Tabel Kesimpulan Pengujian

\begin{tabular}{cccccc}
$\begin{array}{c}\text { Menit } \\
\text { ke- }\end{array}$ & $\begin{array}{c}\text { sumber.MHS } \\
\text { PENDAFTAR }\end{array}$ & staging.camaba & $\begin{array}{c}\text { biadw.camaba } \\
\text { biadw.FactJumla } \\
\text { hCamaba }\end{array}$ & Report & Waktu \\
\hline 0 & insert 11 data & - & - & - & - \\
\hline 1 & - & $\begin{array}{c}\text { insert 11 perubahan } \\
\text { data dari sumber }\end{array}$ & $\begin{array}{c}\text { insert dan } \text { update } \\
11 \text { perubahan data } \\
\text { dari staging }\end{array}$ & $\begin{array}{c}\text { perubahan } \\
\text { tampil di report }\end{array}$ & 1 menit \\
& Total Waktu & & & $\mathbf{1}$ menit
\end{tabular}

\section{Kesimpulan}

Konsep real-time diwujudkan dengan mengintegrasikan CDC dengan tool ETL menggunakan model CDC Pull secara periodik meminta perubahan data, yaitu setiap menit setiap harinya, sehingga mampu memberikan informasi real-time kepada manajemen universitas. SSIS package memproses perubahan data saja dengan menerima sekumpulan record yang merepresentasikan perubahan yang ditangkap sejak siklus permintaan terakhir, sehingga membutuhkan waktu yang singkat dibandingkan me-load semua data. Untuk mengeksekusi 11 perubahan data mulai dari proses insert ke tabel sumber hingga bisa ditampilkan di browser laporan memerlukan waktu satu menit. Dengan cara ini data pada data warehouse selalu sinkron dengan data pada sistem transaksionalnya dengan hanya satu menit penundaan, sehingga dengan semakin tingginya frekuensi periode permintaan perubahan data akan semakin mendekati real-time.

\section{Referensi}

Attachmate Corporation. 2005. Capturing Changes to Host-Based Data Sources, Attacmate Technical Paper, (Online), (http://www.attachmate.com/NR/rdonlyres/2F8775C99CA1-411E-95D9-5415D7EDDB7D/0/tp_capturing_changes.pdf, diakses 18 Januari 2013).

Attunity. 2006. Real Time Business Intelligence Enabling Effective Decision Making: Strategic, Real Time Data Integration Platform With Change Data Capture, Attunity White Paper, (Online), (http://i.zdnet.com/whitepapers/Attunity_Real_Time_Biz_Intelligence.pdf, diakses 18 Januari 2013).

Azvine, B., Cui, Z., Nauck, D.D. \& Majeed, B. 2006. Real Time Business Intelligence for the Adaptive Enterprise. The $3^{\text {rd }}$ IEEE International Conference on Enterprise Computing, E-Commerce, and E-Services, pp. 1-11.

Botan, I., Cho, Y., Derakhshan, R., Dindar, N., Haas, L.M., Kim, K. \& Tatbul, N. 2009. Federated Stream Processing Support for Real-Time Business Intelligence Applications. In BIRTE 2009, pp. 14-31.

Inmon, W.H. 2005. Building the Data Warehouse, Fourth Edition. New York: John Wiley \& Sons,Inc.

Jörg, T. \& Deßloch, S. 2008. Towards Generating ETL Processes for Incremental Loading. In Proceedings of the 2008 International Symposium on Database Engineering \& Applications (IDEAS '08).

Kusnawi. 2008. Aplikasi Data Warehouse untuk Business Intelligence. Jurnal Dasi, vol. 9, no. 1 , pp. 82-91.

McGehee, B. 2008. Brad's Sure Guide to SQL Server 2008. Tasmania: Simple-Talk Publishing.

Ponniah, P. 2010. Data Warehousing Fundamentals, $2^{\text {nd }}$ edition. Singapore: John Wiley \& Sons Inc.

Prasetyo, M.A., Saikhu, A. \& Sarwosri, 2010, Pembuatan Aplikasi OLAP Untuk Pelaporan pada PT. Aneka Tuna Indonesia Menggunakan SQL Server 2005, (Online), (http://digilib.its.ac.id/public/ITS-Undergraduate-9803-Paper.pdf, diakses tanggal 20 
Januari 2014).

Sandu, D.I. 2008. Operational and Real-Time Business Intelligence. Revista Informatica Economică, no.3(47), pp. 33-36.

Tank, D.M., Ganatra, A., Kosta, Y.P., Bhensdadia, C.K. 2010. Speeding ETL Processing in Data Warehouses Using High-Performance Joins for Changed Data Capture (CDC). Advances in Recent Technologies in Communication and Computing (ARTCom), 2010 International Conference, pp.365-368.

Turban, E., Aronson, J.E. \& Liang, T.P. 2004. Decision Support Systems and Intelligent Systems, 7th Edition. New Jersey: Prentice-Hall.

Wilarso, I. 2008. Pemanfaatan Data Warehouse di Perguruan Tinggi Indonesia. Jurnal Sistem Informasi MTI-UI, vol.4, no.1, pp. 47-54. 